\title{
Predicting Video Game Addiction: The Effects of Composite Regulatory Focus and Interpersonal Competence Among Indonesian Teenagers During COVID-19 Pandemic
}

\author{
(D) Yudhi Purwa Nugraha ${ }^{1 *}$, Awalya Awalya², (D) Mulawarman Mulawarman ${ }^{2}$ \\ Universitas Sebelas Maret, Indonesia $^{1}$ \\ Universitas Negeri Semarang, Indonesia ${ }^{2}$ \\ @yudhi.purwa@student.uns.ac.id ${ }^{1}$ *
}

Article Information:

Received November 15, 2020

Revised December 10, 2020

Accepted January 13, 2021

Keywords: addiction; COVID-19; interpersonal competence; regulatory focus theory; video game

\begin{abstract}
Video game addiction is recognized as a mental health problem caused by uncontrolled access to video gaming platforms. Proper assistance and counseling programs based on the addiction causing factors are required to reduce the tendencies of video game addiction. The study aims to identify the correlation between regulatory focus theory and interpersonal competence towards the tendencies of video game addiction. The study is a type of cross-sectional research with the adapted psychological scales. A total of 136 teenagers, consisting of 86 males and 50 females participated in the survey of self-reported video game addiction. The data were analyzed using multiple regression analysis. The findings revealed that regulatory focus and interpersonal competence simultaneously had a significant effect on the tendencies of video game addiction behavior. The findings of the study can provide the basis to provide proper assistance services, in an attempt to reduce the tendencies of video game addiction among teenagers.
\end{abstract}

\section{INTRODUCTION}

Video game addiction is defined as the realization of negative effects that trigger an individual to play game in a lot of frequencies and long duration so that in the long run, the individual's emotion and identity will get affected (Adiningtiyas, 2017; Dailey et al., 2020; Griffiths, 2010; Lemmens et al., 2009). Video game addiction case was firstly reported in 1980 and is increasing until now (Griffiths et al., 2012; Soper \& Miller, 1983). The results of a survey on adolescents aged 14-17 years in Europe show that as much as 1.6\% of adolescents was reported experiencing Internet Gaming Disorder (IGD), and 5.1\% experienced video game addiction (Müller et al., 2015).

Similarly, in Indonesia, more than 10\% of adolescents at Junior High School and Senior High School levels were reported experiencing video game addiction (Jap et al., 2013). The reported individuals were identified based on the criteria of salience, tolerance, mood modification, withdrawal, relapse, conflict, and problem (Griffiths, 2010; Lemmens et al., 2009). It was also reported that video game addiction cases are increasing during COVID-19 pandemic (Amin et al., 2020; Sun et al., 2020). However, there has been no information about the increase of video game addiction by Senior High School students during COVID-19 pandemic.

\section{How to cite:}

E-ISSN:

Published by:
Nugraha, Y., Awalya, A., \& Mulawarman, M. (2021). Predicting Video Game Addiction: The Effects of Composite Regulatory Focus and Interpersonal Competence Among Indonesian Teenagers During COVID-19 Pandemic. Islamic Guidance and Counseling Journal, 4(1). https://doi.org/10.25217/igcj.v4i1.1199 2614-1566 Institut Agama Islam Ma'arif NU (IAIMNU) Metro Lampung 
The absence of control towards the access of video gaming activities by children may trigger their aggressiveness, anxiety, impulsivity, and decreasing academic achievements (Hui et al., 2019; Kim \& Kim, 2015; Simcharoen et al., 2018). The shift IN children's behavior signifies the symptom of mental health issues due to video game addiction (Stockdale \& Coyne, 2018). The case should be distinctively and comprehensively regarded in line with its behavioral causing factors (Paulus et al., 2018; Zajac et al., 2017, 2020). The efforts aim to reveal the causing variables of video game addiction cases, as the basis to arrange proper counseling programs.

In terms of psychosocial perspective, loneliness is the start of video game addiction because it can be a reason by individuals to fulfil social interaction needs (Bhagat et al., 2019; İskender, 2018; Simcharoen et al., 2018). With regards to the notion, ASEAN countries, especially Indonesia also consider interpersonal competence as part of the development (Lee \& Kim, 2016; Sari, 2018; Thomas, 2018). Sugaya et al. (2019) mentioned that poor interpersonal competence in the pattern of parents-children relationship might increase the tendencies of video game addiction. Interpersonal competence is the individual ability to express certain feelings and ideas, in addition to receive and offer particular situational responses verbally and non-verbally (Agustiyana \& Awalya, 2016; Bhagat et al., 2019; Buhrmester et al., 1988; Sari, 2018). Individuals with video game addiction tend to deny the negative impacts of their behavior (Greenfield, 2018; Kim, 2013).

Previous studies revealed different findings regarding interpersonal competence. Chen et al. (2018) stated that users with high interpersonal competence utilized video games to maintain their interpersonal relations in real life. The interpersonal relations established through video gaming activities lead the users to be more frequently getting involved (Hussain et al., 2012). However, individuals with low interpersonal competence tend to use video games as the fulfillment of their social interaction (Dailey et al., 2020). Based on the notion, teenagers with social anxiety and deterrence tend to get addicted to video gaming activities (Kim et al., 2017). The correlation between interpersonal competence and video game addiction among teenagers during the pandemic is considered interesting for research.

Previous studies have offered new insights to identify a number of factors that motivated individuals to get themselves involved in video gaming (Bhagat et al., 2019; Lee et al., 2019) based on the Regulatory Focus Theory (RTF) (Higgins, 1997). RTF defines that every individual possesses a self-regulatory system that consists of promotion focus and prevention focus (Crowe \& Higgins, 1997; Higgins, 1997). The theory explains that users with video game addiction are motivated by their self-regulatory system that affects their behavior and decision-making (Debanne et al., 2014; Higgins et al., 2019). The regulatory focus mechanism significantly relates to the striatum ventral (the part of the brain that coordinates the reward mechanism system) that regulates the individual motivation to achieve certain goals (Scult et al., 2017).

Video game players with high promotion focus tend to expect to achieve their goals by ignoring any possible consequences (Guo \& Spina, 2015; Lee et al., 2013). On the other hand, gamers with prevention focus tend to be aware, avoid losses, and aim at the final goals (Debanne et al., 2014; Fuglestad et al., 2013). Ho et al. (2011) revealed that a number of players utilized video games to escape from particular problems and make their new roles in a different ecosystem.

Lee et al. (2019) even highlighted that solitariness had nothing to do with low interpersonal competence. It is more likely triggered by excessive prevention focus, as part of the causing factors of the decreasing interpersonal competence (İskender, 2018; Lee et al., 2019). According to Winterheld \& Simpson (2016), individuals with excessive prevention focus would rather maintain sound social interaction and posit themselves as the supporters of the interaction within a particular social environment. The utilization of video games as social 
interaction media leads to frequent access that causes addiction (Kim et al., 2017; Wang et al., 2019). Social support based on the condition of certain regulatory focus will encourage positivity and empowerment (Fransen \& Hoeven, 2013). The current research aims to identify the correlation between regulatory focus and interpersonal competence towards the tendencies of video game addiction among teenagers during the COVID-19 pandemic.

\section{Rationale of The Current Study}

Following the survey regarding the utilization of smartphones by teenagers in Ngawi District, Indonesia, the researchers found out a number of issues pertaining to internet utilization that led to the tendencies of video game addiction. Based on the previous study, a number of factors regarding interpersonal competence and motivation (regulatory focus) did affect the tendencies. Therefore, the current research aimed to reveal the correlation between interpersonal competence and regulatory focus towards video game addiction cases among teenagers. With regards to the issue, the researchers utilized three psychological scales, including the Gaming Addiction Scale (Lemmens et al. 2009), Composite Regulatory Focus Scale (Haws et al., 2010), and Interpersonal Competence Questionnaire (Buhrmester et al., 1988).

\section{Hypotheses}

1. Regulatory focus and interpersonal competence simultaneously affect the tendencies of video game addiction among teenagers during the COVID-19 pandemic.

2. Regulatory focus affects the tendencies of video game addiction among teenagers during the COVID-19 pandemic.

3. Interpersonal competence affects the tendencies of video game addiction among teenagers during the COVID-19 pandemic.

\section{METHODS}

\section{Research Design}

The current research implemented a quantitative approach through a cross-sectional design survey. The researchers collaborated with a number of school principals in Ngawi District, Indonesia. They assigned counseling teachers in their respective schools to distribute the link of research scales to their students.

\section{Participants}

The study involved 1,046 Senior High School students in Ngawi District, Indonesia. By referring to Brunborg et al. (2015), the study revealed that 136 students showed symptoms of video game addiction in the category of problematic and addicted. The demographic distribution of those students consisted of 86 males and 50 females aged around 16.02 years. Based on the characteristics of regulatory focus, 93 teenagers possessed the characteristics of promotion focus, while 43 showed prevention focus. With regards to interpersonal competence, 77 teenagers possessed high interpersonal competence, while 59 had low interpersonal competence.

\section{Instruments}

The study utilized three adjusted psychological scales. The adjustment process of the instruments referred to the procedures developed by Lenz et al. (2017). The first instrument is the seven-item Gaming Addiction Scale (GAS) developed by Lemmens et al. (2009) to measure the tendencies of self-reported video game addiction. It consisted of seven questions equipped with a five-point Likert scale, ranging from never (1) to very often (5), e.g., "Pernahkah anda berpikir untuk bermain game sepanjang hari?" and "Apakah anda 
bertengkar dengan orang lain (seperti; keluarga, teman) tentang waktu yang anda habiskan untuk bermain game?". The reliability test used Cronbach's $\alpha=.86$ (Lemmens et al., 2009); Cronbach's $\alpha=.68$ to .82 for the samples in Indonesia (Ulkhaq et al., 2018). The result of the reliability test generated Cronbach's $\alpha=.80$. The students' addiction to video gaming activities was identified based on the criteria developed by Brunborg et al. (2015) and Lin et al. (2019).

Secondly, the Composite Regulatory Focus Scale (CRFS) developed by Haws et al. (2010) was applied to measure the self-reported regulatory focus. The scale consisted of ten questions equipped with a seven-point of Likert scale, ranging from totally unsuitable with me (1) to totally suitable with me (7), e.g., "Saya merasa sudah membuat kemajuan untuk menuju kesuksesan dalam hidup" and "Saya khawatir membuat kesalahan". The reliability test used Cronbach's $\alpha=.79$ for the promotion focus and Cronbach's $\alpha=.74$ for the prevention focus (Haws et al., 2010); Cronbach's $\alpha=.74$ for the promotion focus and Cronbach's $\alpha=.68$ for the prevention focus (Naletelich \& Spears, 2020). The study generated prevention focus Cronbach's $\alpha=.65$ and promotion focus Cronbach's $\alpha=.65$. The students were identified based on the larger value between the promotion focus and prevention focus.

Thirdly, the study utilized the Interpersonal Competence Questionnaire (ICQ) that was developed by Buhrmester et al. (1988) and revised in 1992. The scale consisted of 40 questions equipped with a five-point Likert scale, ranging from very poor (1) to very agile (5), e.g., "Seberapa baik Saudara dalam membuat orang untuk mengikuti apa yang Saudara inginkan?" and "Seberapa baik Saudara dalam menyuarakan keinginan dan pendapat?". The reliability test used Cronbach's $\alpha=.77$ (negative response) to .86 (support and emotional initiative) (Buhrmester et al., 1988), in addition to Cronbach's $\alpha=.91$ (Lee et al., 2019). The test generated Cronbach's $\alpha=.94$. The responses of the students indicated their interpersonal competence.

\section{Procedures}

The data collection was conducted from 31 August to 10 September 2020 during the COVID-19 pandemic. It was around six months after the confirmation of the first infection case in Indonesia (Detik.com, 2020). The research instruments were designed using Google Form and distributed by a number of counseling teachers to the students. Around 1,046 students participated in the online survey. The data of the respondents' responses were compiled in Google Sheet. The respondents were classified based on the categories of their addiction according to Brunborg et al. (2015), ranging from problematic to addicted. Following the classification, the study applied multiple linear regression analysis using IBM SPSS to test the hypotheses.

\section{Data Analysis}

The data analysis implemented a multiple linear regression to explore the correlation between variables, including the dependent and independent variables. It utilized IBM SPSS.

\section{RESULTS AND DISCUSSION}

\section{Results}

The instruments were distributed through a Google Form link to the Senior High School students in Ngawi District, Indonesia through the assistance of the counseling teachers. The survey was held from 31 August to 10 September 2020. The description of the tendencies of video game addiction among the teenagers in Ngawi District is presented in Table 1.

A total of 1,046 teenagers aged around 14 to 19 years that consisted of 400 males and 646 females stated their consent to participate in this study. Brunborg et al. (2015) classified the tendencies of video game addiction into four categories. A total of 136 teenagers $(13 \%)$ 
Table 1. Participants Demographical Information $(\mathrm{N}=136)$

\begin{tabular}{lcccc}
\hline Variables & $\mathrm{F}$ & $\mathrm{M}$ & $\mathrm{SD}$ & $\%$ \\
\hline Teenagers with tendencies of video game addiction & 136 & 19.404 & 3.400 & 100 \\
Category (problematic) & 120 & & & 88.2 \\
Category (addicted) & 16 & & & 11,8 \\
14 to 19 years old & 136 & 16.029 & .698 & 100 \\
Gender & & & & \\
$\quad$ Male & 86 & & & 63.2 \\
Male & 50 & & & 36.8 \\
Regulatory focus & 136 & 51.147 & 6.506 & 100 \\
$\quad$ Promotion focus & 93 & & & 68.4 \\
$\quad$ Prevention focus & 43 & & & 31.6 \\
Interpersonal competence & 136 & 124.551 & 19.713 & 100 \\
$\quad$ High & 77 & & & 56.6 \\
$\quad$ Low & 59 & & & 43.4 \\
\hline
\end{tabular}

Table 2. Model Summary

\begin{tabular}{ccccccccc}
\hline Model & R & R Square & Adjusted R Square & Std. Error of the Estimate & F Change & df1 & df2 & p \\
\hline 1 & $.212^{\mathrm{a}}$ & .045 & .031 & 3.348 & 3.140 & 2 & 133 & .046 \\
\hline
\end{tabular}

Note:

Predictors $=$ (constant), interpersonal competence, regulatory focus

Dependent variable $=$ tendencies of video game addiction

Table 3. Coefficients

\begin{tabular}{|c|c|c|c|c|c|}
\hline \multirow{2}{*}{ Variables } & \multicolumn{2}{|c|}{ Unstandardized Coefficients } & \multirow{2}{*}{$\frac{\text { Standardized Coefficients }}{\text { Beta }}$} & \multirow{2}{*}{$\mathrm{t}$} & \multirow{2}{*}{$\mathrm{p}$} \\
\hline & $\mathrm{B}$ & Std. Error & & & \\
\hline (Constant) & 25.472 & & & 10.162 & .000 \\
\hline Regulatory focus & -.100 & .048 & -.192 & -2.091 & .038 \\
\hline Interpersonal competence & -.008 & .016 & -.004 & -.478 & .633 \\
\hline
\end{tabular}

Note:

Dependent variable $=$ tendencies of video game addiction

showed the tendencies of video game addiction in two categories, including problematic and addicted. They consisted of 86 males and 50 females. The average score of the problematic and addicted category generated $\mathrm{M}=19.404$ and $\mathrm{SD}=3.40$.

Regarding the video game addiction based on the characteristics of regulatory focus with the problematic and addicted category, 93 teenagers $(68.4 \%)$ possessed promotion focus, while 43 teenagers $(31.6 \%)$ tended to have prevention focus. The average score of the regulatory focus of the teenagers with problematic and addicted category generated $\mathrm{M}=51.15$ and $\mathrm{SD}=6.51$. Regarding the interpersonal competence, 77 teenagers $(56.6 \%)$ possessed high interpersonal competence, while $59(43.4 \%)$ possessed low interpersonal competence. The average score of their interpersonal competence in the problematic and addicted category was $\mathrm{M}=124.56$ and $\mathrm{SD}=19.71$.

Proceeding the analysis, a multiple linear regression model was applied to identify the correlation between regulatory focus and interpersonal competence towards the tendencies of video game addiction among teenagers within the problematic and addicted category. The hypotheses were examined and stated eligible to be followed up with multiple linear regression analysis.

The multiple linear regression results (Table 3) confirmed that regulatory focus and interpersonal competence were the predictors of the tendencies of video game addiction among teenagers. The correlation of the variances was $4.5 \%$ with $\mathrm{F}(2.133)=3.348$ and $\mathrm{p}>$ .05 . Meanwhile, the regulatory focus significantly contributed to the model $(\mathrm{B}=-.100$ and $\mathrm{p}<$ $.05)$. On the other hand, personal competence insignificantly contributed to the model $(\mathrm{B}=-$ .008 and $\mathrm{p}=.633$ ). 


\section{Discussion}

The survey on the video game addiction in Ngawi District, Indonesia revealed that $13 \%$ of the teenagers tended to experience addiction in the problematic and addicted category. During the pandemic, the video game addiction cases increased by $2.85 \%$, compared to the initial report that was only 10.15\% (Detik.com, 2020; Jap et al., 2013). A similar increase was also reported by China and the UK (Nicola et al., 2020; Sun et al., 2020).

The social restrictions and lockdown policies implemented by the Indonesian Government have hindered the public daily activities. Therefore, video gaming activities appeared as the solution (Király et al., 2020; Marston \& Kowert, 2020). For a number of players, such a condition is an opportunity to be more frequently active on the gaming platforms. They were engaged in gaming and unconsciously inclined to the video game addiction (Amin et al., 2020).

Based on the first hypothesis, regulatory focus and interpersonal competence simultaneously affected the tendencies of video game addiction among teenagers. Regarding the previous study, teenagers with low prevention focus and low interpersonal competence tended to experience solitariness, which was recognized as the indication of video game addiction (Lee et al., 2019). Players that related their self-identities and video gaming activities were prone to get addicted (Dailey et al., 2020).

Distinctively from Lee et al. (2019), the current study revealed that regulatory focus significantly encouraged the players to get involved more in video gaming. They were motivated to maintain their achievements (Choi, 2020). Players with promotion focus were mostly motivated to achieve their goals, such as reaching the upper levels. Meanwhile, players with prevention focus generally used video games as the mechanism to avoid losses (Guo \& Spina, 2015; Lee et al., 2013). In the end, self-involvement in more frequent video gaming activities led to the negative impacts that tended to the addiction (King \& Delfabbro, 2014; Lam, 2014; Şalvarlı \& Griffiths, 2019; Van Rooij et al., 2011).

\section{Limitations and Suggestions}

The current study has several limitations, including the absence of video game classification (online or offline). Furthermore, it was only performed in Ngawi region by involving the teenagers as the samples. Further studies are suggested to use a larger number of samples from various regions in Indonesia. An experimental research to reduce the tendencies of video game addiction in terms of regulatory focus and interpersonal competence is also recommended.

\section{Implications}

The study has provided additional information regarding the effects of regulatory focus and interpersonal competence on the tendencies of video game addiction. The findings of the study can provide the basis to provide proper assistance services, in an attempt to reduce the tendencies of video game addiction among teenagers.

\section{CONCLUSION}

The survey revealed the increasing tendencies of video game addiction among teenagers in Indonesia during the COVID-19 pandemic. Both regulatory focus and interpersonal competence simultaneously affected the tendencies of addiction. Teenagers with promotion focus and prevention focus tended to use video games to achieve their ultimate goals that eventually led to addictive behavior. The findings of the study can serve as the basis to develop proper counseling services, in an attempt to reduce the tendencies of video game addiction. Further studies are suggested to involve a larger number of samples in various regions in Indonesia. The initiative of an experimental research to reduce the tendencies of 
video game addiction in terms of regulatory focus and interpersonal competence is also recommended.

\section{ACKNOWLEDGMENT}

The authors express their gratitude to the counseling teachers and Senior High School students in Ngawi District, Indonesia that have participated in the study. The authors also thank all parties that generously support the objectives of the study.

\section{AUTHOR CONTRIBUTIONS STATEMENT}

YD was in charge of designing the research and collecting the data. Meanwhile, AW and MN provided guidance and supervision during the research.

\section{REFERENCES}

Adiningtiyas, S. W. (2017). Peran guru dalam mengatasi kecanduan game online. Jurnal Kopasta, 4(1), 28-40. http://dx.doi.org/10.33373/kop.v4i1.1121

Agustiyana, T., \& Awalya. (2016). Meningkatkan kemampuan komunikasi interpersonal siswa melalui layanan penguasaan konten dengan teknik sosiodrama. Indonesian Journal of Guidance and Counseling: Theory and Application, 5(2). https://doi.org/10.15294/IJGC.V4I4.8831

Amin, K. P., Griffiths, M. D., \& Dsouza, D. D. (2020). Online gaming during the COVID-19 pandemic in India: strategies for work-life balance. International Journal of Mental Health and Addiction. https://doi.org/10.1007/s11469-020-00358-1

Bhagat, S., Jeong, E. J., \& Kim, D. J. (2019). The role of individuals' need for online social interactions and interpersonal incompetence in digital game addiction. International Journal of Human-Computer Interaction, O(00), 1-15. https://doi.org/10.1080/10447318.2019.1654696

Brunborg, G. S., Hanss, D., Mentzoni, R. A., \& Pallesen, S. (2015). Core and peripheral criteria of video game addiction in the game addiction scale for adolescents. Cyberpsychology, Behavior, and Social Networking, 18(5), 280-285. https://doi.org/10.1089/cyber.2014.0509

Buhrmester, D., Furman, W., Wittenberg, M. T., \& Reis, H. T. (1988). Five domains of interpersonal competence in peer relationships. Journal of Personality and Social Psychology, 55(6), 991-1008. https://doi.org/10.1037/0022-3514.55.6.991

Chen, L., Liu, R., Zeng, H., Xu, X., Zhu, R., Sharma, M., \& Zhao, Y. (2018). Predicting the time spent playing computer and mobile games among medical undergraduate students using interpersonal relations and social cognitive theory: a cross-sectional survey in Chongqing, China. International Journal of Environmental Research and Public Health, 15(8). https://doi.org/10.3390/ijerph15081664

Choi, Y. (2020). A study of the antecedents of game engagement and the moderating effect of the self-identity of collaboration. International Journal of E-Collaboration, 16(2), 1-11. https://doi.org/10.4018/ijec.2020040101

Crowe, E., \& Higgins, E. T. (1997). Regulatory focus and strategic inclinations: Promotion and prevention in decision-making. Organizational Behavior and Human Decision Processes, 69(2), 117-132. https://doi.org/10.1006/ obhd.1996.2675

D. Griffiths, M., J. Kuss, D., \& L. King, D. (2012). Video game addiction: Past, present and future. Current Psychiatry Reviews, 8(4), 308-318. https://doi.org/10.2174/157340012803520414

Dailey, S. L., Howard, K., Ceballos, N., \& Grimes, T. (2020). A biopsychosocial approach to understanding social media addiction. Human Behavior and Emerging Technologies., February, 1-10. https://doi.org/10.1002/hbe2.182 
Debanne, T., Angel, V., \& Fontayne, P. (2014). Decision-making during games by professional handball coaches using regulatory focus theory. Journal of Applied Sport Psychology, 26(1), 111-124. https://doi.org/10.1080/10413200.2013.801370

Detik.com, D. (2020). Kapan sebenarnya corona pertama kali masuk RI?. News: Detik.Com. Google

Fransen, M. L., \& Hoeven, C. L. ter. (2013). Matching the Message: The Role of Regulatory Fit in Negative Managerial Communication. Communication Research, 40(6), 818-837. https://doi.org/10.1177/0093650211427140

Fuglestad, P. T., Rothman, A. J., \& Jeffery, R. W. (2013). The effects of regulatory focus on responding to and avoiding slips in a longitudinal study of smoking cessation. Basic and $\begin{array}{llll}\text { Applied Social } & \text { Psychology, 35(5), 426-435. }\end{array}$ https://doi.org/10.1080/01973533.2013.823619

Greenfield, D. N. (2017). Treatment considerations in internet and video game addiction: A qualitative discussion. Child and Adolescent Psychiatric Clinics of North America, 118. https://doi.org/10.1016/j.chc.2017.11.007

Griffiths, M. (2010). Online video gaming: What should educational psychologists know? Educational Psychology in Practice, 26(1), 35-40. https://doi.org/10.1080/02667360903522769

Guo, T., \& Spina, R. (2015). Regulatory focus affects predictions of the future. Personality and Social Psychology Bulletin, 41(2), 214-223. https://doi.org/10.1177/0146167214561194

Haws, K. L., Dholakia, U. M., \& Bearden, W. O. (2010). An assessment of chronic regulatory focus measures. Journal of Marketing Research, 47(5), 967-982. https://doi.org/10.1509/jmkr.47.5.967

Higgins, E. T. (1997). Beyond pleasure and pain. American Psychologist, 52(12), 1280-1300. https://doi.org/10.1037/0003- 066X.52.12.1280

Higgins, E. T., Nakkawita, E., \& Cornwell, J. F. M. (2019). Beyond outcomes: How regulatory focus motivates consumer goal pursuit processes. Consumer Psychology Review, June, 1-15. https://doi.org/10.1002/arcp.1052

Ho, S. H., Putthiwanit, C., \& Lin, C. Y. (2011). May I Continue or Should I Stop? The Effects of Regulatory Focus and Message Framings on Video Game Players' Selfcontrol. International Journal of Business and Social Science,2(12). https://mpra.ub.uni-muenchen.de/id/eprint/33544

Hui, B. P. H., Wu, A. M. S., Siu, N. Y. F., Chung, M. L., \& Pun, N. (2019). The effects of need satisfaction and dissatisfaction on flourishing among young chinese gamers: The mediating role of internet gaming disorder. International Journal of Environmental Research and Public Health, 16(22), 1-14. https://doi.org/10.3390/ijerph16224367

Hussain, Z., Griffiths, M. D., \& Baguley, T. (2012). Online gaming addiction: Classification, prediction and associated risk factors. Addiction Research and Theory, 5(20), 359-371. https://doi.org/10.3109/16066359.2011.640442

İskender, M. (2018). Investigation of the effects of social self-confidence, social loneliness and family emotional loneliness variables on internet addiction. Malaysian Online Journal of Educational Technology, 6(3), 1-10. https://doi.org/10.17220/mojet.2018.03.001

Jap, T., Tiatri, S., Jaya, E. S., \& Suteja, M. S. (2013). The development of Indonesian online game addiction questionnaire. PLoS ONE, 8(4), 4-9. https://doi.org/10.1371/journal.pone.0061098

Kim, E. Y., Cho, I., \& Kim, E. J. (2017). Structural equation model of smartphone addiction based on adult attachment theory: Mediating effects of loneliness and depression. Asian Nursing Research, 11(2), 92-97. https://doi.org/10.1016/j.anr.2017.05.002 
Kim, H. (2013). Exercise rehabilitation for smartphone addiction. Journal of Exercise Rehabilitation, 9(6), 500-505. https://doi.org/10.12965/jer.130080

Kim, K., \& Kim, K. (2015). Internet game addiction, parental attachment, and parenting of adolescents in South Korea. Journal of Child and Adolescent Substance Abuse, 24(6), 366-371. https://doi.org/10.1080/ 1067828X.2013.872063

King, D. L., \& Delfabbro, P. H. (2014). Clinical psychology review the cognitive psychology of internet gaming disorder. Clinical Psychology Review, 34(4), 298-308. https://doi.org/10.1016/j.cpr.2014.03.006

Király, O., Potenza, M. N., Stein, D. J., King, D. L., Hodgins, D. C., Saunders, J. B., Griffiths, M. D., Gjoneska, B., Billieux, J., Brand, M., Abbott, M. W., Chamberlain, S. R., Corazza, O., Burkauskas, J., Sales, C. M. D., Montag, C., Lochner, C., Grünblatt, E., Wegmann, E., ... Demetrovics, Z. (2020). Preventing problematic internet use during the COVID-19 pandemic: Consensus guidance. Comprehensive Psychiatry, 100, 1-4. https://doi.org/10.1016/j.comppsych.2020.152180

Lam, L. T. (2014). Internet gaming addiction, problematic use of the internet, and sleep problems: A systematic review. Current Psychiatry Reports, 16(4). https://doi.org/10.1007/s11920-014-0444-1

Lee, C., \& Kim, O. (2016). Predictors of online game addiction among Korean adolescents. Addiction Research and Theory, 25(1), 58-66. https://doi.org/10.1080/16066359.2016.1198474

Lee, J., Ko, D. W., \& Lee, H. (2019). Loneliness, regulatory focus, inter-personal competence, and online game addiction: A moderated mediation model. Internet Research, 29(2), 381-394. https://doi.org/10.1108/IntR-01-2018-0020

Lee, Y. H., Heeter, C., Magerko, B., \& Medler, B. (2013). Feeling right about how you play: The effects of regulatory fit in games for learning. Games and Culture, 8(4), 238-258. https://doi.org/10.1177/1555412013498818

Lemmens, J. S., Valkenburg, P. M., \& Peter, J. (2009). Development and validation of a game addiction scale for adolescents. Media Psychology, 12(1), 77-95. https://doi.org/10.1080/15213260802669458

Lenz, A. S., Soler, I. G., Dell'Aquilla, J., \& Uribe, P. M. (2017). Translation and crosscultural adaptation of assessments for use in counseling research. Measurement and Evaluation in Counseling and Development, 50(4), 224-231. https://doi.org/10.1080/07481756.2017.1320947

Lin, C. Y., Imani, V., Broström, A., Årestedt, K., Pakpour, A. H., \& Griffiths, M. D. (2019). Evaluating the psychometric properties of the 7-Item persian game addiction scale for Iranian adolescents. Frontiers in Psychology, 10(FEB), 1-13. https://doi.org/10.3389/fpsyg.2019.00149

Marston, H. R., \& Kowert, R. (2020). What role can videogames play in the COVID-19 pandemic? Emerald Open Research, 34. https://doi.org/10.35241/emeraldopenres.13727.1

Müller, K. W., Janikian, M., Dreier, M., Wölfling, K., Beutel, M. E., Tzavara, C., Richardson, C., \& Tsitsika, A. (2015). Regular gaming behavior and internet gaming disorder in European adolescents: Results from a cross-national representative survey of prevalence, predictors, and psychopathological correlates. European Child and Adolescent Psychiatry, 24(5), 565-574. https://doi.org/10.1007/s00787-014-0611-2

Naletelich, K., \& Spears, N. (2020). Analogical reasoning and regulatory focus: Using the creative process to enhance consumer-brand outcomes within a co-creation context. European Journal of Marketing, 54(6), 1355-1381. https://doi.org/10.1108/EJM-052018-0354

Nicola, M., Alsafi, Z., Sohrabi, C., Kerwan, A., \& Al-jabir, A. (2020). The socio-economic 
implications of the coronavirus pandemic (COVID-19): A review. International Journal of Surgery, 78, 185-193. https://doi.org/10.1016/j.ijsu.2020.04.018

Paulus, F. W., Ohmann, S., von Gontard, A., \& Popow, C. (2018). Internet gaming disorder in children and adolescents: A systematic review. Developmental Medicine and Child Neurology, 60(7), 645-659. https://doi.org/10.1111/dmcn.13754

Şalvarlı, Ş. İ., \& Griffiths, M. D. (2019). Internet gaming disorder and its associated personality traits: A systematic review using PRISMA guidelines. International Journal of Mental Health and Addiction. https://doi.org/10.1007/s11469-019-00081-6

Sari, Y. N. (2018). The urgency of developing trust and interpersonal communication skills of students through role playing. Konselor, 7(3), 89-94. https://doi.org/10.24036/02018738684-0-00

Scult, M. A., Knodt, A. R., Hanson, J. L., Ryoo, M., Adcock, R. A., Hariri, A. R., \& Strauman, T. J. (2017). Individual differences in regulatory focus predict neural response to reward. Social Neuroscience, 12(4), 419-429. https://doi.org/10.1080/17470919.2016.1178170

Simcharoen, S., Pinyopornpanish, M., Haoprom, P., Kuntawong, P., Wongpakaran, N., \& Wongpakaran, T. (2018). Prevalence, associated factors and impact of loneliness and interpersonal problems on internet addiction: A study in Chiang Mai medical students. Asian Journal of Psychiatry, 31(October 2017), 2-7. https://doi.org/10.1016/j.ajp.2017.12.017

Soper, W. B., \& Miller, M. J. (1983). Junk-time junkies: An emerging addiction among students. The School Counselor, 31(1), 40-43. http://www.jstor.org/stable/23900931

Stockdale, L., \& Coyne, S. M. (2018). Video game addiction in emerging adulthood: Crosssectional evidence of pathology in video game addicts as compared to matched healthy controls. Journal of Affective Disorders, 225, 265-272. https://doi.org/10.1016/j.jad.2017.08.045

Sugaya, N., Shirasaka, T., Takahashi, K., \& Kanda, H. (2019). Bio-psychosocial factors of children and adolescents with internet gaming disorder: A systematic review. BioPsychoSocial Medicine, 13(1), 1-16. https://doi.org/10.1186/s13030-019-0144-5

Sun, Y., Li, Y., Bao, Y., Meng, S., Sun, Y., Schumann, G., Kosten, T., Strang, J., Lu, L., \& Shi, J. (2020). Brief report: Increased addictive internet and substance use behavior during the COVID-19 pandemic in China. American Journal on Addictions, 29(4), 268270. https://doi.org/10.1111/ajad.13066

Thomas, D. (2018). Motivational beliefs, social media addiction, and interpersonal communication skill among international students in Thailand. International Forum, 21(2), 153-169. Google Scholar

Ulkhaq, M. M., Rozaq, R., Ramadhani, R., Heldianti, R., Fajri, A., \& Akshinta, P. Y. (2018). Validity and reliability assessment of the game addiction scale: an empirical finding from Indonesia. ACM International Conference Proceeding Series, 120-124. https://doi.org/10.1145/3288155.3288158

Van Rooij, A. J., Schoenmakers, T. M., Vermulst, A. A., Van Den Eijnden, R. J. J. M., \& Van De Mheen, D. (2011). Online video game addiction: Identification of addicted adolescent gamers. Addiction, 106(1), 205-212. https://doi.org/10.1111/j.13600443.2010.03104.x

Wang, J. L., Sheng, J. R., \& Wang, H. Z. (2019). The association between mobile game addiction and depression, social anxiety, and loneliness. Frontiers in Public Health, 7(SEP), 5-10. https://doi.org/10.3389/fpubh.2019.00247

Winterheld, H. A., \& Simpson, J. A. (2016). Regulatory Focus and the Interpersonal Dynamics of Romantic Partners' Personal Goal Discussions. Journal of Personality, 84(3), 277-290. https://doi.org/10.1111/jopy.12158 
Zajac, K., Ginley, M. K., \& Chang, R. (2020). Treatments of internet gaming disorder: A systematic review of the evidence. Expert Review of Neurotherapeutics, 20(1), 85-93. https://doi.org/10.1080/14737175.2020.1671824

Zajac, K., Ginley, M. K., Chang, R., \& Petry, N. M. (2017). Treatments for internet gaming disorder and internet addiction: A systematic review. Psychology of Addictive Behaviors, 31(8), 979-994. https://doi.org/10.1037/adb0000315

Copyright holder :

(C) Nugraha, Y., Awalya, A., \& Mulawarman, M. (2021)

First publication right :

Islamic Guidance and Counseling Journa

This article is licensed under: 